\title{
NOTES.
}

\section{ON THE PRESENCE OF BINUCLEATE CELLS IN THE ASCOMYCETES.}

Some time ago I indicated, from a morphological standpoint, the origin of the Protobasidiomycetes and the Basidiomycetes from conidial forms of the Ascomycetes ${ }^{1}$.

In a criticism on this paper Harper ${ }^{2}$ remarks as follows :-

'The widespread occurrence of regularly binucleate cells in the Basidiomycetes, with the additional evidence that these cells reproduce by conjugate division and constitute the reproductive series (Keimbahn) in each individual through at least a considerable part of its life-history, leading up to the formation of basidia, while no such cells are found in the Ascomycetes either in vegetative or ascogenous hyphae, shows that the two groups are widely separated phylogenetically. In the face of such differences, resemblances of outer form and method of spore-formation between conidiophores and basidia must be regarded as superficial and of uncertain value, and as wholly inadequate evidence for the conclusion Massee wishes to draw.'

Through lack of appreciation of the value of nuclei in indicating affinity or descent no special search was made for binucleate cells in the Ascomycetes. Quite recently, however, during an investigation of a disease of the cultivated mushroom (Agaricus campestris) caused by Hypomyces perniciosum, a fungus belonging to the Ascomycetes, it was observed that the conidial form of the Hypomyces known as Mycogone had the cells of the hyphae and the conidia constantly binucleate. It was also observed that the two nuclei present in the
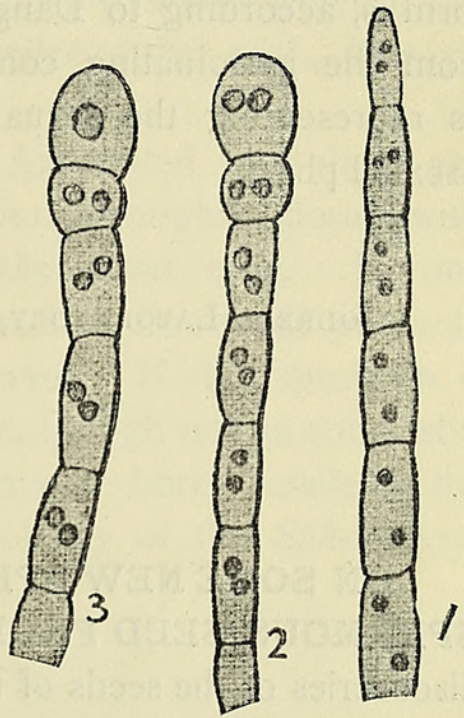

FIG. 7. Binucleate cells in conidial form (Mycogone) of Hypomyces perniciosum. I. Vegetative hypha. 2. Conidiophore with terminal conidium containing two nuclei. 3. Conidiophore showing the terminal conidium after the fusion of its two nuclei. conidium fused at an early stage of development, and that on germination the germtube of the conidium consisted of uninucleate cells.

The cells of Exoascus deformans, one of the Ascomycetes, are binucleate.

In Sclerotinia fructigena, also one of the Ascomycetes, the conidial condition long known as Monilia fructigena, has both hyphal cells and conidia multinucleate, whereas in Sclerotinia aucupariae, an allied species, both hyphal cells and conidia of the conidial form are uninucleate.

1 Journ. Linn. Soc., 34, p. 438 (1900).

${ }^{2}$ Bot. Gaz., 33, p. I (1902).

[Annals of Botany, Vol. XIX. No. LXXIV. April, 1905.] 
In the genus Cystopus fertilization is effected in $C$. candidus by the fusion of two nuclei, whereas in an allied species, $C$. bliti, about one hundred nuclei fuse in pairs to effect the same object.

Finally, in the Uredineae binucleate cells are usual during one phase of the life-cycle, but in Entyloma glauci, one of an allied group, the cells during this same phase are multinucleate.

The above examples illustrate only some of the variants as to number of nuclei in the cells of closely allied species, after which much faith is necessary to admit the value of the number of nuclei present in cells as indicating phylogenetic affinities.

Returning to the conidial form of Hypomyces perniciosum, where the binucleate cells are reproduced by conjugate division, or, in other words, where the two nuclei in a cell divide simultaneously, viewed from Dangeard's standpoint the fusing of the two nuclei in the conidium is a sexual act, and the conidium becomes an oogonium; hence what is considered by common consent to be an asexual conidial form is, according to Dangeard, the sexual form, and the ascophore stage emanating from the germinating conidium and having uninucleate cells, which is considered as representing the sexual phase, becomes according to Dangeard a conidial or asexual phase.

GEO. MASSEE.

Jodrell Laboratory, Kew.

ON SOME NEW SPECIES OF LAGENOSTOMA ${ }^{1}$ : A TYPE OF PTERIDO. SPERMOUS SEED FROM THE COAL MEASURES (ABSTRACT).-The recent discoveries of the seeds of two genera of the Cycadofilices, Lyginodendron and Medullosa, mark an important epoch in the history of our knowledge of Palaeozoic plants. As a corollary of this work, attention has been called afresh to the impressions or casts of seed-like bodies which occur, here and there, in the sandstones and shales of the Coal Measures, with the result that two new species, described here, have been identified as members of the genus Lagenostoma. Although the anatomical structure is not preserved in either case, these seeds in their external morphology agree so closely with the three species of Lagenostoma previously recorded from petrified material that there can be no hesitation in referring them to the same genus. In view of the recent attribution of the seed Lagenostoma Lomaxi to Lyginodendron by Professor Oliver and Dr. Scott, it is highly probable that these new species belonged either to that genus or to some closely related member of the Lyginodendreae. These specimens also throw light on the habit of these plants, especially with regard to the manner in which the female organs were borne, a character which is, with rare exceptions, extremely difficult to ascertain in the case of fossil plants owing to the fragmentary nature of the evidence.

1 Abstract of a paper read before the Rayal Society on February 23, 1905. 


\section{$2 \mathrm{BHL}$ Biodiversity Heritage Library}

Massee, George. 1905. "On the presence of binucleate cells in the Ascomycetes." Annals of botany 19, 325-326.

https://doi.org/10.1093/oxfordjournals.aob.a089003.

View This Item Online: https://www.biodiversitylibrary.org/item/233541

DOI: https://doi.org/10.1093/oxfordjournals.aob.a089003

Permalink: https://www.biodiversitylibrary.org/partpdf/318801

\section{Holding Institution}

Smithsonian Libraries

\section{Sponsored by}

Biodiversity Heritage Library

\section{Copyright \& Reuse}

Copyright Status: Not in copyright. The BHL knows of no copyright restrictions on this item.

This document was created from content at the Biodiversity Heritage Library, the world's largest open access digital library for biodiversity literature and archives. Visit BHL at https://www.biodiversitylibrary.org. 